\title{
Repurchase Intention among Mobile Shoppers with Mediating Effect of Satisfaction on Mobile Shopping
}

\author{
Nur Ain Mohd Paiz ${ }^{1}$, Mass Hareeza Ali ${ }^{1}$, Abdul Rashid Abdullah ${ }^{1} \&$ Zuraina Dato Mansor $^{1}$ \\ ${ }^{1}$ School of Business and Economics Department of Management and Marketing, Universiti Putra Malaysia, \\ Selangor, Malaysia \\ Correspondence: Nur Ain Mohd Paiz, School of Business and Economics, Department of Management and \\ Marketing, Universiti Putra Malaysia, Selangor, Malaysia. E-mail: aienpaiz@gmail.com
}

Received: January 21, 2021

Accepted: March 17, 2021

Online Published: May 19, 2021

doi:10.5539/ijbm.v16n7p1

URL: https://doi.org/10.5539/ijbm.v16n7p1

\begin{abstract}
Good continuation of mobile shoppers' intention could ensure sustainability in mobile shopping, thus the study of consumer behavior including service quality, perceived value, trust and satisfaction is essential in order to understand their needs. The question is whether the mobile shopping in Malaysia has provided sufficient mobile websites or apps facilities to gain the repurchase intention of mobile shoppers. However, there are several issues arise such as bad reviews or comments, lack of communication and fake online sellers that may affect mobile shoppers' behaviour. This research aims to examine the relationship between service quality (SQ), perceived value (PV) and trust (TR) mediated by mobile shoppers' satisfaction (CS) with repurchase intention (RI). 427 usable questionnaires were collected from the mobile shoppers around Kuala Lumpur and Selangor. The data was analyzed using SPSS and Structural Equation Modelling in SmartPLS. The results suggested that there is a significant relationship between SQ, PV and TR on CS. Besides, CS mediates the relationship between SQ, PV and TR with RI. The research has extended the body of knowledge in mobile shopping studies. The findings contribute valuable theoretical and managerial implications that can enhance mobile shopping services.
\end{abstract}

Keywords: customer satisfaction, trust, perceived value, service quality, repurchase intention, mobile shopping

\section{Introduction}

Mobile devices and technology have grown exponentially in recent years. The rapid migration of technology to mobile has transformed the consumer experience with various aspects of daily life, and created new business opportunities across the market (Chao et al., 2013). For instance, mobile shopping is one of mobile channels have been introduced in the retail market (Ghazali et al., 2018; Phong et al., 2018). Mobile shopping has emerged as a new shopping channel for consumers in line with the rapid technological shift towards mobile transactions (Kalinić et al., 2019). Referring to Wong et al., (2012), the definition of mobile shopping as the ability to purchase goods and services anywhere through a mobile device. Consumer choose for online shopping is turning to mobile shopping platforms, and this is becoming a popular behavioral trend among online shopping alternatives for contemporary consumers to search for information, browse for products, comparing price and specification, and purchasing products or services using mobile devices at anytime and anywhere (Madan \& Yadav 2018; Hung et al., 2012) leading, thus, to the formation of mobile shoppers' behaviour. Today, the demand for online purchasing using mobile technology has increasing trend in society today and Malaysian people are ranked among the most passionate mobile shoppers which contributed to growing competitive advantages intensively in the retailing market (Artigas \& Barajas-Portas, 2019; Liu et al., 2019; Ghazali et al., 2018; Phong et al., 2018). While mobile shopping brings about many benefits, and grows in popularity; consumers are still exposed to risks due to the nature of online shopping, as well as the number of online purchase complaints. The statement of National Consumer Complaints Centre (NCCC) reported that online purchases are the highest case of fraud with total losses amounting to RM 6 million in 2018. Online purchase fraud occurs when items purchased online do not reach consumers, receive goods that not follw specification, receive different and defect goods. Mobile shopping platform is believed to create major challenges in consumer perception and purchasing behaviour (Liu et al., 2019; Madan \& Yadav, 2018; Marriott et al., 2017). It is, therefore, essential to identify the factors influencing mobile shoppers repurchase behaviour. Previous studies have examined a range of factors influencing consumer behaviour in different context. These include service quality (Rita et al., 2019; Mohammad 
Salameh et al., 2018), perceived value (Liu et al., 2015; Carlson et al., 2015) and trust (Artigas \& Barajas-Portas, 2019; Trivedi \& Yadav, 2020). However, there have been few attempts to comprehensively examine consumer behaviour in mobile shopping context. Therefore, the primary purpose of this study was to investigate the factors that influence on mobile shoppers' satisfaction and repurchase intention towards mobile shopping. The findings of this research could provide a better understanding toward behaviour of mobile shoppers.

\section{Literature Review and Research Hypotheses Development}

\subsection{Repurchase Intention (RI)}

$\mathrm{RI}$ is a psychological behaviour and one of the main drivers that motivate buyers to continue buying products or services (Trivedi \& Yadav, 2018). A higher repurchase intention denotes a higher probability of the consumer buying the item (Schiffman and Kaunk, 2000). Repurchase intention can define as "the subjective probability that a customer (i.e. experienced customers) will continue to purchase a product from the same online seller" (Chiu et al., 2014). This research defines repurchase intention as refers to the strength of consumer's willingness to repurchase same product or service through mobile shopping. The reason for RI is mainly refer on past purchase experiences (Kuo et al., 2009). Understanding customer RI is beneficial because satisfied customers tend to continue their relationship with certain sellers rather than dissatisfied (Ibzan et al., 2016). In the existing literature, RI has been discussed in service context (Trivedi \& Yadav, 2020; Adekunle \& Ejachi, 2018). Trivedi \& Yadav (2020) found that consumers RI has a significantly affect on consumer buying behaviour in e-commerce. Similarly, Adekunle and Ejachi, (2018) indicated that consumers behavioural intention towards online shopping is a significant predictor of RI. This is because consumers who have a high RI would increase the consumers' rebuying behaviour. While many researches had been carried out in RI study in different contexts but there has been limited empirical studies on mobile shopping context. Hence, this research is set out to examine RI as a dependent variable empirically to enrich the body of knowledge in this context.

\subsection{Service Quality (SQ)}

Service quality is an essential research topic in consumer behaviour areas and has been broadly studied in various service sectors, including banking (Boonlertvanich, 2019), healthcare (Fatima et al., 2018) and tourism (Keshavarz \& Jamshidi, 2018). Parasuraman et al. (2005) define service quality as "the extent to which a website facilitates efficient, effective shopping, purchasing and delivery". This research defines service quality as mobile shoppers 'overall evaluation and perceptions of service quality towards mobile shopping. The most common approach to measure service quality is by employing the SERVQUAL model (Parasuraman et al., 1985). Parasuraman et al. (1985) introduced SERVQUAL as an instrument designed to measure the five dimensions of reliability, tangibles, empathy, responsiveness and assurance. This model is still popular and currently used in many studies (Altunas \& Kansu, 2019; Yilmaz et al., 2018; Kumar et al., 2018). However, the initial concept of service quality assessment was not well implemented in the virtual environment (Parasuraman \& Grewal, 2000; Parasuraman et al., 2005). A user friendly and effective mobile website or app is fundamental in ensuring that service quality in mobile shopping is achieved. Many researchers modified SERVQUAL into several models that suit the online service context (Rita et al., 2019). Thus, the eTailQ model developed by Wolfinbarger and Gilly (2003), in line with the purpose of this research to capture a holistic view of the process of developing user behavior. The eTailQ model measures from the beginning to the end of the transaction, including information search, website navigation, ordering, interaction, delivery and satisfaction with the ordered product (Wolfinbarger \& Gilly, 2003). They simplified the multiple items scales to four dimensions, including website design, fulfilment or reliability, security or privacy, and customer service. This model currently is applied in many studies (Rita et al., 2019; Blut, 2016). There have been existing studies of service quality in various contexts explored by several researchers (Boonlertvanich, 2019; Rita et al., 2019) that focussed on the specific dimensions of service quality towards mobile shopping. Boonlertvanich (2019) highlighted the specific service quality dimensions by examining the behaviour of consumers. Meanwhile, Rita et al., (2019) specifically explored the role of specific dimensions of service quality in explaining Indonesian online consumer behaviour. Based on the review of the past research in service quality mostly different context but less attention in mobile shopping. This research aims to bridge the gap in the existing literature by proposing service quality as the factor that could influence mobile shoppers' behaviour. Various researchers have revealed that service quality has a positive relationship with satisfaction is shown by several studies (Trivedi \& Yadav, 2020; Adekunle \& Ejechi, 2018). Trivedi and Yadav (2020) found that service quality was positively associated with satisfaction. Adekunle and Ejechi (2018) assess how relationship service quality affects mobile buyer satisfaction, where it shows service quality is an important factor influencing mobile shopppers' satisfaction in mobile shopping. This research should provide further research to examine the relationship between service quality and satisfaction with mobile shopping. These prior researchers have revealed a positive and significant relationship between 
service quality and customer satisfaction. Similarly, the relationship is expected to occur in a mobile shopping context, leading to a first research hypothesis as follows:

H1: Service quality positively influence mobile shoppers' satisfaction

\subsection{Perceived Value (PV)}

Perceived value is a polymorphic concept that have been widely discussed in various contexts, included traditional mall shopping (Kesari \& Atulkar, 2016), online shopping (Carlson et al., 2015; Chiu et al., 2014) and mobile shopping (Liu et al., 2015; Xu et al., 2015). Perceived value can be defined as "the consumer's overall assessment of the utility of a product based on perceptions of what is received and what is given" (Zeithaml, 1988). Tsao et al., (2016) define perceived value as "the feelings of consumers aroused by comparing benefits and sacrifices from online retail activities in which shopping websites endeavour to establish a long-term relationship with the consumers by providing services that are valuable to them". Therefore, this research defines perceived value as a consumer's perception of net benefits derived from the trade-off between the benefits and the associated sacrifices derived from the mobile shopping. In this view, perceived value encompasses two components: the benefits earned and the sacrifices made (Liu et al., 2015). Valuable exchanges for the sacrifice component and consumer benefits are important arguments not only in the offline but also online environment (Tankovic \& Benazic, 2018). Customer perceived value in the mobile shopping is crucial factor and that is why it is necessary to understand the role of perceived value in mobile shoppers' behaviour. Sellers strive to maintain long-term and stable relationships with buyers and receive regular orders, while buyers strive to reduce their purchase costs as well as their profitability (Gan \& Wang, 2017). The value that customers feel has received a lot of attention in the field of marketing strategy because it achieves sustainable competitive advantage that plays an important role in predicting buying behavior (Tankovic \& Benazic, 2018). Perceived value is a important construct in influencing consumer behaviour in various contexts (Keshavarz \& Jamshidi, 2018; Tankovic \& Benazic, 2018). Keshavarz and Jamshidi (2018) and Tankovic and Benazic (2018) indicated that very little discussion of the perceived value is being conducted as an empirical study. This study highlights that there is still a gap in understanding the perceived value especially in the context of mobile shopping. Several researchers agreed that perceived value has a significant influence on customer satisfaction because the company that delivers high quality services at reasonable prices, able to satisfy customer needs better (Kataria \& Saini 2019; Han et al., 2018; Gan \& Wang, 2017). Han et al., (2018) and Gan and Wang (2017) explored the effects of the perceived value on customer satisfaction. They highlighted that perceived value occurred by the customer judgement after the service providing process that lead to customer satisfaction. In addition, researchers also found that perceived value are positively contributes and improves consumer satisfaction in oral care sector (Kataria \& Saini, 2019). This previous study found that perceived value is an indicator to determine customer satisfaction. Thus, this research suggests that there is a need to provide further research on the relationship between perceived value and customer satisfaction with mobile shopping. This research aims to understand the customer satisfaction of mobile buyers by emphasizing the influence of value felt by the consumer, and this leads to the second research hypothesis as follows:

\section{H2: Perceived value positively influence mobile shoppers' satisfaction}

\subsection{Trust (TR)}

TR has been the focus of a great deal of attention and extensively study in numerous contexts such as banking (Chang \& Hung, 2018), retailing (Wobker et al., 2015), online shopping (Raman, 2019) and mobile shopping (Jimenez et al., 2016). Given the massive expansion of mobile devices, findings in the marketing literature have shown that trust plays an important role as a precedent for good perception for mobile shopping as well as maintaining long-term buyer and seller relationships. It also helps by fostering real trust among consumers that is likely to stabilise, grow, encourage consumers to use online service more extensively (Artigas \& Portas, 2019). Carter et al., (2014) define trust as "the faith that the customer has in the online vendor that customers will deal in a fair manner". This research defines trust as the consumer belief, confident or expectation of mobile shopping that fulfil their needs and not taking unexpected actions produces negative results. A great number of prior studies have demonstrated that trust is the most vital aspect that determines a consumer's behaviour (Chang \& Hung, 2018; Raman, 2019; Jimenez et al., 2016). Chang and Hung (2018) stated that trust is an important predictor of behavioral outcomes in the context of mobile banking. Raman (2019) indicated that trust is generally considered essential to maintaining long-term customer relationships. Jimenez et al., (2016) also found that trust has always been considered a critical factor in the context of online services and has been recognized significantly to influence the outcome of user behavior. In the existing literature, the trust has been discussed in many aspects including banking, online shopping and also mobile shopping. Surprisingly, within these many 
discussions on trust, the empirical studies on trust are limited particularly the ones that highlight how trust influences on consumer behaviour. Other existing studies on trust mostly concentrates on the conceptual study while limited empirical studies based on the online consumer perspective. Therefore, the research intended to fulfil the gap by proposing trust as a factor that influences mobile shoppers' behaviour. Empirical evidence studies of electronic and mobile commerce suggest that trust correlates with customer satisfaction and is a necessary component of adoption behaviours (Kalinic et al., 2019; Trivedi \& Yadar, 2018; Thakur, 2018). Kalinic et al., (2019) showed that trust was one of the main drivers of mobile shopping adoption in Mexico. Trivedi and Yadar (2018) use trust as a determinant of mobile shopping continuance in Taiwan. Consistent with extant studies Thakur (2018) study on mobile commerce adoption highlights that trust affects consumers' behavioural intention. These previous studies discovered that trust is the most significant determinant of repurchase intention, especially in mobile shopping. The results of previous research studies show that the higher the level of consumer trust, the higher the level of consumer intention to buy, and therefore, the easier it is for online stores to attract, maintain and maintain long-term relationships with them. Although leading researchers have conducted several studies on online shopping, this research covers only aspects of the beliefs and intentions of online shopping are limited. Therefore, it would be interesting to see further research on the influence of mobile shoppers' trust on satisfaction towards mobile shopping which leads to the third research hypothesis as follows:

H3: Trust positively influence mobile shoppers' satisfaction

\subsection{Customer Satisfaction (CS)}

CS is an affective psychological process rather than only a cognitive process alone (Kataria \& Saini, 2019). It is recognised to be an essential factor that affects foster long lasting relationships between the consumer and seller, and further generates outcome consumer behaviour (Pham \& Ahammad, 2017). Research on CS has received a great attention from both marketing academicians and practitioners. There are some discussions regarding the concept of CS in the existing literature. The concept of CS has been developed by the literature in different contexts such as banking (Boonlertvanich, 2019), hospitality (Shahzadi et al., 2018), oral care (Kataria \& Saini, 2019), online shopping (Trivedi \& Yadav, 2018) and mobile shopping (Thakur, 2018). Anderson and Srinivasan (2003) define customer satisfaction as "the customer's happiness with about his or her prior purchasing experience with the websites". Artigas and Portas (2019) explain customer satisfaction as "an emotional response to the degree and speed with which mobile shopping is adopted, and on the other hand, as a response to the expected benefits of using mobile shopping". This research defines customer satisfaction as the mobile shopper's overall positive or negative feeling based on the purchasing experience from mobile shopping. Numerous studies have attempted to relate consumer satisfaction in the context of banking (Boonlertvanich, 2019; Chang \& Hung, 2018); mobile shopping (Artigas \& Portas, 2019) and online shopping (Trivedi \& Yadav, 2018; Rita et al., 2018). Boonlertvanich (2019) and Chang and Hung (2018) identified that customer satisfaction is an essential precursor to one's repurchase intention. Artigas and Portas (2019) found that satisfaction with mobile shopping is decisive in the intention to commit to a mobile device. Similarly, Trivedi and Yadav (2018) and Rita et al., (2018) indicated that satisfaction serves as a

mediator when identifying potential problems; therefore, it is important for the group in this study, and the results show that it influences the relationship between repurchase intentions. While many researchers have been carrying out studies on satisfaction, there have been few empirical studies on mobile shoppers' satisfaction particularly in Malaysia. The research on customer satisfaction in mobile shopping studies have overlooked these issues empirically. CS can be an intermediary between its factors and consumer buyback decisions. Factors such as quality of service, perceived value and trust can be a source of CS; therefore, CS can mediate the relationship between these factors and the intention to repurchase. Therefore, this leads to the fourth study hypothesis as follows:

H4a: Customer satisfaction mediates the effect of service quality on repurchase intention.

H4b: Customer satisfaction mediates the effect of perceived value on repurchase intention.

H4c: Customer satisfaction mediates the effect of trust on repurchase intention.

This research proposes a conceptual model to explain mobile shoppers' behaviour based on established relationships among service quality (website design, fulfilment/reliability, security/privacy and customer service), perceived value, trust and customer satisfaction, repurchase intention as refer to Figure 1. 


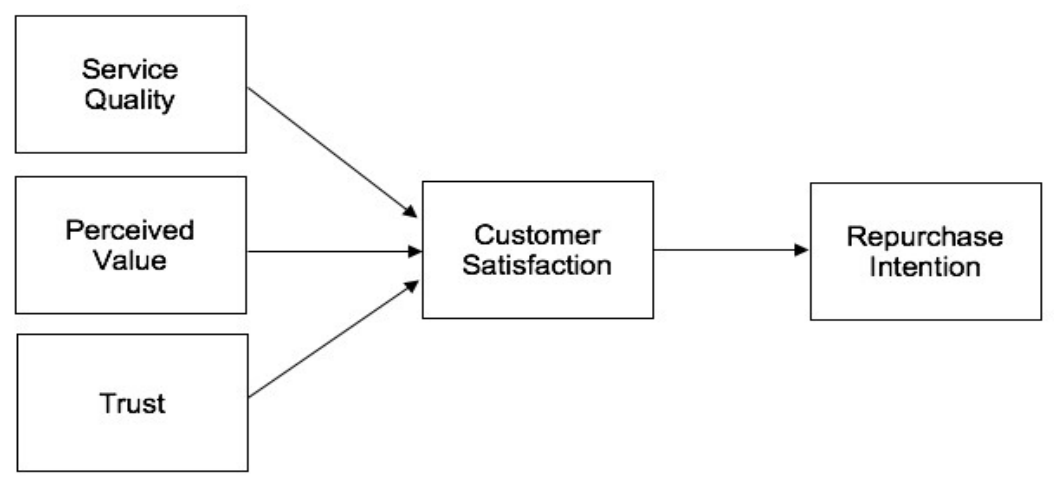

Figure 1. Conceptual model

\section{Research Methodology}

This research applied a survey-based methodology to collect the data. The data was collected through the manual distribution of the survey questionnaire. The structured questionnaires were distributed to selected shopping malls. This research was conducted at shopping malls in Malaysia with two major cities, namely Kuala Lumpur and Selangor. These shopping malls were selected as research settings due to their large number of shoppers, where their mobile shoppers are being selected as sample elements. A total of 460 hard copies of the survey questionnaires. Out of these 450 were collected. After eliminating the unusable questionnaires, more than $80 \%$ of the questionnaires were used for analyzing purposes, which the total number of 427 . Therefore, if based on the suggestion by Krejcie and Morgan (1970), the required sample size is by the minimum number of the sample size required is 384. As the survey questionnaire was fully administrated, the anticipated return rate is $90 \%$ thus the following is based on the anticipated return rate calculation by Bartlett et al., (2001). Therefore, the final sample size is 427. The data was analyzed using SPSS version 22.0 and Partial Least Structured Equation Modelling (PLS-SEM) technique.

\section{Results}

\subsection{Descriptive Statistics Analysis}

There are four demographic characteristics presented using the frequency test and percentage, and these demographic characteristics were gender, age, education and income and highlights the length of shopping hours spent on the mobile shopping and the frequency of assessing mobile shopping using a mobile device. From the demographic statistics, the use of mobile devices to shop online is more popular among women consumers of those below 34 years old with degree holder. From this result, it is interesting to note that most respondents often do online shopping via mobile device to purchase products. From the table, it can be seen that skewness for all constructs was between -2 to +2 thus meeting the requirement. Meanwhile for kurtosis, all the values were between -7 to +7 thereby fulfilling the requirement for normality.

\subsection{Measurement Model Analysis}

The measurement model involves the assessment of the validity and reliability of the indicators. In the assessment of the measurement model, three main assessment criteria are needed at the outset. These three assessments are composite reliability (CR) and indicator loadings, Average Variance Extracted (AVE), and discriminant validity (Hair et al., 2017). As for this research, all observed constructs (SQ, PV, TR, CS and RI) composite reliability was above the minimum threshold of 0.7 and all AVEs were greater than 0.5 after the process of item deletion (Hair et al., 2017). These constructs met the composite reliability and convergent validity requirement, and the indicator loading, composite reliability (CR) and average variance extracted (AVE) of the reflective constructs as shown in Table 1. Hence, a better approach is used in this study to evaluate the measurement model for discriminant validity which is the Heterotrait-Monotrait Ratio of Correlations (HTMT) in order to assess discriminant validity. HTMT can achieve higher specificity and sensitivity rates of between $97 \%$ to $99 \%$ (Henseler et al., 2015). The result showed neither lower nor upper confidence interval includes a value of 1. Thus, discriminant validity was achieved based on the HTMT inferences. 
Table 1 . The result of convergent validity for measurement model analysis

\begin{tabular}{|c|c|c|c|c|}
\hline Construct & Item & Loadings & $\mathrm{CR}$ & AVE \\
\hline \multirow[t]{4}{*}{ Service Quality (SQ) } & SQA & 0.760 & 0.848 & 0.582 \\
\hline & SQB & 0.765 & & \\
\hline & SQC & 0.767 & & \\
\hline & SQD & 0.817 & & \\
\hline \multirow[t]{4}{*}{ Perceived Value (PV) } & PV1 & 0.825 & 0.887 & 0.662 \\
\hline & PV2 & 0.851 & & \\
\hline & PV3 & 0.776 & & \\
\hline & PV4 & 0.800 & & \\
\hline \multirow[t]{4}{*}{ Trust (TR) } & TR1 & 0.752 & 0.904 & 0.611 \\
\hline & TR2 & 0.739 & & \\
\hline & TR3 & 0.735 & & \\
\hline & TR4 & 0.754 & & \\
\hline \multirow[t]{4}{*}{ Customer Satisfaction (CS) } & CS1 & 0.757 & 0.925 & 0.551 \\
\hline & $\mathrm{CS} 2$ & 0.772 & & \\
\hline & $\mathrm{CS} 3$ & 0.747 & & \\
\hline & CS4 & 0.757 & & \\
\hline \multirow[t]{4}{*}{ Repurchase Intention (RI) } & RI1 & 0.725 & 0.915 & 0.608 \\
\hline & RI2 & 0.753 & & \\
\hline & RI3 & 0.794 & & \\
\hline & RI4 & 0.829 & & \\
\hline
\end{tabular}

\subsection{Structural Model Analysis}

The structural model represents a set of one or more dependent relationships linking the model structures, and is most useful in representing the interrelationship of variables between dependent relationships (Hair et al., 2014). There are five steps to assess the structural model that consists of Collinearity Issues, Path Coefficient, Level of $\mathrm{R}^{2}$, Level of Effect Size $\left(\mathrm{f}^{2}\right)$ and Predictive Relevance $\left(\mathrm{Q}^{2}\right)$. The table illustrated the result of structural model. First assessment, the result of collinearity issue indicated that all the VIF values for each individual construct are less than 5 and 3.3; thus, indicating collinearity is not a concern in the research. The second step in evaluating the structural model is to evaluate the road coefficient. There are three direct hypotheses developed in the relationship between constructs. To test the level of importance in PLS-SEM, t-values for all paths were generated using bootstrapping procedure. Based on the assessment of the path coefficient, three relationships $(\mathrm{H} 1, \mathrm{H} 2, \mathrm{H} 3)$ were found to have results of the t-value $>1.645$, thus significant at the 0.05 level of significance. Next, the $\mathrm{R}^{2}$ value for two endogenous constructs, namely RI and CS. The $\mathrm{R}^{2}$ values of 0.670 for RI indicates that the exogenous constructs, namely written, account for $67 \%$ of the variance in RI. Similarly, the $\mathrm{R}^{2}$ value of 0.699 for that CS reflected $69.9 \%$ of variance. The results indicate that PV $(0.208)$ has a substantial effect in producing the $\mathrm{R}^{2}$ for CS. In contrast, the result also suggests that SQ $(0.197)$ and TR (0.105) has a close to medium effect in producing the $\mathrm{R}^{2}$ for $\mathrm{CS}$. The fifth step in evaluating a structural model is to assess the predictive power. The results show that the relevance of the $\mathrm{Q}^{2}$ forecast from CS has a value of 0.381 and the RI has a value of 0.403 , indicating that the model has a predictive relevance based on the endogenous construct because the value of $\mathrm{Q}^{2}$ far exceeds zero. 
Table 2. The result of structural model analysis

\begin{tabular}{cccccl}
\hline Relationship & Std. Beta & t-value & p-value & $\mathrm{f}^{2}$ & Decision \\
\hline H1: SQ - CS & 0.266 & 5.295 & 0.000 & 0.197 & significant \\
H1: PV - CS & 0.349 & 6.325 & 0.000 & 0.208 & significant \\
H1: TR - CS & 0.271 & 5.067 & 0.000 & 0.105 & significant \\
\hline
\end{tabular}

\subsection{Mediation Analysis}

In order to assess the mediating effect of a construct in PLS-SEM, interaction terms between the mediator and the predicting variables were created to examine the effect on endogenous variables. The bootstrapping analysis has shown that all three indirect effects are significant with t-value. The indirect effect 95\% Boot Confidence Interval Bias Corrected: $[\mathrm{LL}=0.138, \mathrm{UL}=0.305],[\mathrm{LL}=0.205, \mathrm{UL}=0.377]$ and $[\mathrm{LL}=0.136, \mathrm{UL}=0.309]$ where do not straddle a 0 in between indicating there is mediation (Preacher \& Hayes, 2004, 2008). Based on the results, we can conclude that the effect of mediation is statistically significant as mentioned in Table 3 . After established the presence of the mediation effect, the analysis proceeded with the mediation test for the individual paths. Specifically, the results indicated a significant interaction for all three indirect effect. Thus, we can determine that the mediation result can be characterized as a partial mediation because the VAF values of $51 \%$ (SQ), 39\% (PV) and 45\% (TR) which means the VAF range become greater than $20 \%$ and less than $80 \%$.

Table 3. The result of mediation analysis

\begin{tabular}{|c|c|c|c|c|c|c|c|}
\hline Hypothesis & Relationship & $\underline{\text { Std. Beta }}$ & t-value & p-value & Decision & VAF Value & Type of Mediation \\
\hline $\mathrm{H} 4 \mathrm{a}$ & $\mathrm{SQ}-\mathrm{CS}-\mathrm{RI}$ & 0.220 & 5.215 & 0.000 & Significant & $51 \%$ & Partial \\
\hline $\mathrm{H} 4 \mathrm{~b}$ & $\mathrm{PV}-\mathrm{CS}-\mathrm{RI}$ & 0.286 & 6.426 & 0.000 & Significant & $39 \%$ & Partial \\
\hline $\mathrm{H} 4 \mathrm{c}$ & $\mathrm{TR}-\mathrm{CS}-\mathrm{RI}$ & 0.221 & 4.828 & 0.000 & Significant & $45 \%$ & Partial \\
\hline
\end{tabular}

\section{Discussion and Conclusion}

This research identified SQ factor as a good predictor of repurchase intention with supported eTailQ dimensions of website design, fulfilment or reliability, security or privacy and customer services succed in building mobile shoppers' satisfaction. Previous research of Rita et al., (2019) have identified SQ is important factor in generating repurchase intention in mobile shopping. Practitioners should invest more in developing of mobile access and giving priority to develop of features in mobile websites or apps make mobile friendly system. Besides that, this research result supported that PV has a significant influence on CS and parallel with Han et al., (2018) indicated that mobile shoppers with a higher level of PV will be more likely to develop CS. Mobile shoppers not only focus on the features and quality of the product but also pay more attention to the shopping experience, they will tend to develop satisfaction, and thus intend to use mobile shopping. The practitioners need to establish value-oriented strategies by developing mobile shopping systems and services by considering the cost-benefit rations in mobile shoppers' perceptions Also, this result supported that there is a relationship between TR and CS and consistent to the existing research by Artigas and Portas (2019) where they showed that TR has an effect on CS that emerged from consumer behaviour mobile shoppers. The finding of this research stated that mobile shopper is convinced that the mobile sites or apps are secure and reliable, mobile shoppers tends to feel some comfort when using mobile shopping and tends to be more satisfied. The practitioners should introduce satisfaction guarantee policy as a measure of building trust that minimizes risk perception. In addition, columns of reviews and testimonials that reduce mobile shoppers' doubts and concerns about product or service quality should be added to the mobile stores. This study also examined the mediation effect of CS in the relationship between repurchase intention and its factors (SQ, PV and TR), which oppose the finding of Fatima et al., (2018); Hussain (2016); and Kataria and Saini (2019). These findings suggest that CS is shown to be an important variable in RI and an important mediator in some relationships and strongly supports the findings of Gan and Wang (2017); and Kataria and Saini (2019). With these findings, implying that service providers should take measures to develop CS by strengthening SQ, PV and TR which further stimulates customers' RI. Based on 
the results, it can be deduced that the objective of this research was met. In addition, the supported results parallel with some of the existing literatures. This study has some limitations that can be addressed in future research. First, there is limited data collection, where this research focus in Kuala Lumpur and Selangor only, not be generalized for all the mobile shoppers of the entire country. Future research should conduct similar to others countries to gain a deeper and wider spectrum of respondents, increase generalizability of findings. Second, the sample size of this research is small because the respondents are mobile shoppers only, research outcomes may lack generalizability. Future research should larger and broader participants. The broadly applicable to different type of people will be given stability results. Finally, this research uses the cross-sectional research, where Consumer perceptions and intentions will change over time. Future research should consider longitudal research to capture variations of these behavior, necessary to be measured across times. Therefore, the findings of this research were hoped to provide information needed in strategizing, preparing and improving the mobile shopping in attracting and accepting potential Malaysian consumers. This is hopefully could improve the Malaysian consumers accepting for sustainability of Malaysia economy.

\section{References}

Adekunle, S., \& Ejechi, J. (2018). Modelling repurchase intention among smartphones users in Nigeria. Journal of Modelling in Management, 13(4), 794-814. https://doi.org/10.1108/JM2-12-2017-0138

Altuntas, S., \& Kansu, S. (2019). An innovative and integrated approach based on SERVQUAL, QFD and FMEA for service quality improvement: A case study. Kybernetes. 49(10), 2419-2453. https://doi.org/10.1108/K-04-2019-0269

Anderson, R. E., \& Srinivasan, S. S. (2003). E-satisfaction and e-loyalty: a contingency framework. Psychology and Marketing, 20(2), 123-138. https://doi.org/10.1002/mar.10063

Artigas, E. M., \& Portas, K. B. (2019). Precedents of the satisfaction of mobile shoppers. A cross-country analysis. Electronic Commerce Research and Applications. https://doi.org/10.1016/j.elerap.2019.100919

Bartlet, J, E., Kotrlik, J. W., \& Higgins, C. C. (2001). Organizational research: determining appropriate sample size in survey research appropriate sample size in survey research. Information Technology, Learning and Performance Journal, 19(1), 43.

Blut, M. (2016). E-service quality: development of a hierarchical model. Journal of Retailing, 92(4), 500-517. https://doi.org/10.1016/j.jretai.2016.09.002

Boonlertvanich, K. (2019). Service quality, satisfaction, trust, and loyalty: the moderating role of main-bank and wealth status. International Journal of Bank Marketing, 37(1), 278-302. https://doi.org/10.1108/IJBM-02-2018-0021

Carlson, J., O'Cass, A., \& Ahrholdt, D. (2015). Assessing customers' perceived value of the online channel of multichannel retailers: a two-country examination. Journal of Retailing and Consumer Services, 27, 90-102. https://doi.org/10.1016/j.jretconser.2015.07.008

Carter, M., Wright, R., Thatcher, J. B., \& Klein, R. (2014). Understanding online customers' ties to merchants: the moderating influence of trust on the relationship between switching costs and e-loyalty. European Journal of Information Systems, 23(2),185-204. https://doi.org/10.1057/ejis.2012.55

Chang, C., \& Hung, J. (2018). The effects of service recovery and relational selling behaviour on trust, satisfaction, and loyalty. International Journal of Bank Marketing, 36(7), 1437-1454. https://doi.org/10.1108/IJBM-07-2017-0160

Chao, C. W., Reid, M., \& Mavondo, F. (2013). Global consumer innovativeness and consumer electronic product adoption. Asia Pacific Journal of Marketing and Logistics, 25(4), 614-630. https://doi.org/10.1108/APJML-02-2013-0025

Chiu, C. M., Wang, E. T. G., Fang, Y. H., \& Huang, H. Y. (2014). Understanding customers' repeat purchase intentions in $\mathrm{B} 2 \mathrm{C}$ e-commerce: the roles of utilitarian value, hedonic value and perceived risk. Information Systems Journal, 24(1), 85-114. https://doi.org/10.1111/j.1365-2575.2012.00407

Fatima, T., Malik, S., \& Shabbir, A. (2018). Hospital healthcare service quality, patient satisfaction and loyalty: An investigation in context of private healthcare systems. International Journal of Quality and Reliability Management, 35(6), 1195-1214. https://doi.org/10.1108/IJQRM-02-2017-0031

Gan, C., \& Wang, W. (2017). The influence of perceived value on purchase intention in social commerce context. Internet Research, 27(4), 772-785. https://doi.org/10.1108/IntR-06-2016-0164 
Ghazali, E., Mutum, D. S., Jiu, H. C., \& Nguyen, B. (2018). Do consumers want mobile commerce? A closer look at M-shopping and technology adoption in Malaysia. Asia Pacific Journal of Marketing and Logistics, 30(4), 1064-1086. https://doi.org/10.1108/APJML-05-2017-0093

Hair, J. F., Gabriel, M. L. D., Da, S., \& Patel, V. K. (2014). AMOS Covariance Based Structural Equation Modelling (CB-SEM): Guidelines on its application as a marketing research tool. Revista Brasileira de Marketing, 13(2), 44-55.

Hair, J. F., Tomas, G. M. H., Ringle, C. M., \& Sarstedt, M. (2017). A Primer on Partial Least Square Structural Equation Modelling (PLS-SEM) (2nd ed.).

Han, H., Lee, M., \& Kim, W. (2018). Role of shopping quality, hedonic/utilitarian shopping experiences, trust, satisfaction and perceived barriers in triggering customer post-purchase intentions at airports. International Journal of Contemporary Hospitality Management, 30(10), 3059-3082. https://doi.org/10.1108/IJCHM-09-2017-0563

Henseler, J., Ringle, C. M., \& Sarstedt, M. (2015). A new criterion for assessing discriminant validity in variance-based structural equation modelling. Journal of the Academy of Marketing Science, 43(1), 115-135. https://doi.org/10.1007/s11747-014-0403-8

Hung, M. C., Yang, S. T., \& Hsieh, T. C. (2012). An examination of the determinants of mobile shopping continuance. International Journal of Electronic Business Management, 10(1), 29-37.

Ibzan, E., Balarabe, F., \& Jakada, B. (2016). Consumer satisfaction and repurchase intentions. Developing Country Studies, 6(2), 96-100.

Jimenez, N., San-Martin, S. \& Azuela, J. (2016). Trust and satisfaction: the keys to client loyalty in mobile commerce. Academia Revista Latinoamericana de Administración, 29(4), 486-510. https://doi.org/10.1108/ARLA-12-2014-0213

Kalinić, Z., Marinković, V., Djordjevic, A., \& Liebana-Cabanillas, F. (2019). What drives customer satisfaction and word of mouth in mobile commerce services? A UTAUT2-based analytical approach. Journal of Enterprise Information Management, 33(1), 71-94. https://doi.org/10.1108/JEIM-05-2019-0136

Kataria, S., \& Saini, V. (2019). The mediating impact of customer satisfaction in relation of brand equity and brand loyalty: An empirical synthesis and re-examination. South Asian Journal of Business Studies, 9(1), 62-87. https://doi.org/10.1108/SAJBS-03-2019-0046

Kesari, B., \& Atulkar, S. (2016). Satisfaction of mall shoppers: a study on perceived utilitarian and hedonic shopping values. Journal of Retailing and Consumer Services, 31, 22-31. https://doi.org/10.1016/j.jretconser.2016.03.005

Keshavarz, Y., \& Jamshidi, D. (2018). Service quality evaluation and the mediating role of perceived value and customer satisfaction in customer loyalty. International Journal of Tourism Cities, 4(2), 220-244. https://doi.org/10.1108/IJTC-09-2017-0044

Krejcie, R. V., \& Morgan, D. W. (1970). Determining sample size for research activities. Educational and Psychological Measurement, 38(1), 607-610. https://doi.org/10.1177/001316447003000308

Kumar, M., Sujit, K., \& Charles, V. (2018). Deriving managerial implications through SERVQUAL gap elasticity in UAE banking. International Journal of Quality and Reliability Management, 35(4), 940-964. https://doi.org/10.1108/IJQRM-10-2016-0176

Kuo, Y. F., Wu, C. M., and Deng, W. J. (2009). The relationships among service quality, perceived value, customer satisfaction, and post-purchase intention in mobile value-added services. Computers in Human Behavior, 25(4), 887-896. https://doi.org/10.1016/j.chb.2009.03.003

Liu, F., Zhao, X., Chau, P., \& Tang, Q. (2015). Roles of perceived value and individual differences in the acceptance of mobile coupon applications. Internet Research, 25(3), 471-495. https://doi.org/10.1108/IntR-02-2014-0053

Lui, Y., Li, Q., Edu, T., Jozsa, L., \& Negricea, I. C. (2019). Mobile shopping platform characteristics as consumer behaviour determinants. Asia Pacific Journal of Marketing and Logistics, 32(7), 1565-1587 https://doi.org/10.1108/APJML-05-2019-0308

Madan, K., \& Yadav, R. (2018). Understanding and predicting antecedents of mobile shopping adoption: A developing country perspective. Asia Pacific Journal of Marketing and Logistics, 30(1), 139-162. https://doi.org/10.1108/APJML-02-2017-0023 
Marriott, H. R., Williams, M. D., \& Dwivedi, Y. (2017). What do we know about consumer m-shopping behaviour? International Journal of Retail and Distribution Management, 45(6), 568-586. https://doi.org/10.1108/IJRDM-09-2016-0164

MCMC. (2018). E-Commerce Consumers Survey 2018.

Mohammad Salameh, A., Ahmad, H., Zulhumadi, F., \& Abubakar, F. (2018). Relationships between system quality, service quality, and customer satisfaction: M-commerce in the Jordanian context. Journal of Systems and Information Technology, 20(1), 73-102. https://doi.org/10.1108/JSIT-03-2017-0016

Parasuraman, A., \& Grewal, D. (2000). The impact of technology on the quality value-loyalty chain: a research agenda. Journal of the Academy of Marketing Science, 28(1),168-174. https://doi.org/10.1177/0092070300281015

Parasuraman, A., Zeithaml, V. A., \& Berry, L. L. (1985). A conceptual model of service quality and its implications for future research. Journal of Marketing, 49(4), 41-50. https://doi.org/10.1177/002224298504900403

Parasuraman, A., Zeithaml, V. A., \& Malhotra, A. (2005). E-S-QUAL a multiple item scale for assessing electronic service quality. Journal of Service Research, 7(3), 213-233. https://doi.org/10.1177/1094670504271156

Phama, T. S. H., \& Ahammad, M. F. (2017). Antecedents and consequences of online customer satisfaction: A holistic process perspective. Technological Forecasting and Social Change, 124, 332-342. https://doi.org/10.1016/j.techfore.2017.04.003

Phong. N.D., Khoi, H.K., \& Le, A.N.H. (2018). Factors affecting mobile shopping: a Vietnamese perspective. Journal of Asian Business and Economic Studies, 25(2), 186-205. https://doi.org/10.1108/JABES-05-2018-0012

Preacher, K. J., \& Hayes, A. F. (2004). SPSS and SAS procedures for estimating indirect effect in simple mediation models. Behaviour Research Methods, Instruments and Computers, 36(4), 717-731. https://doi.org/10.3758/BF03206553

Preacher, K. J., \& Hayes, A. F. (2008). Asymptotic and resampling strategies for assessing and comparing indirect effects in multiple mediator model behaviour. Research Methods, 40(3), 879-891. https://doi.org/10.3758/BRM.40.3.879

Raman, P. (2019). Understanding female consumers' intention to shop online: The role of trust, convenience and customer service. Asia Pacific Journal of Marketing and Logistics, 31(4), 1138-1160. https://doi.org/10.1108/APJML-10-2018-0396

Rita, P., Oliveira, T., \& Farisa, A. (2019). The impact of e-service quality and customer satisfaction on customer behaviour in online shopping. Heliyon, 5. https://doi.org/10.1016/j.heliyon.2019.e02690

Schiffman, L. G., \& Kanuk, L. L. (2004). Consumer behavior (8th ed.). Upper Saddle River, New Jersey: Pearson Prentice Hall.

Shahzadi, M., Malik, S., Ahmad, M., \& Shabbir, A. (2018). Perceptions of fine dining restaurants in Pakistan: What influences customer satisfaction and behavioural intentions. International Journal of Quality and Reliability Management, 35(3), 635-655. https://doi.org/10.1108/IJQRM-07-2016-0113

Tankovic, A. C., \& Benazic, D. (2018). The perception of e-servicescape and its influence on perceived e-shopping value and customer loyalty. Online Information Review, 42(7), 1124-1145. https://doi.org/10.1108/OIR-12-2016-0354

Thakur, R. (2018). The role of self-efficacy and customer satisfaction in driving loyalty to the mobile shopping application. International Journal of Retail and Distribution Management, 46(3), 283-303, https://doi.org/10.1108/IJRDM-11-2016-0214

Trivedi, S. K., \& Yadav, M. (2020). Repurchase intentions in Y generation: mediation of trust and e-satisfaction. Marketing Intelligence and Planning, 38(4), 401-415. https://doi.org/10.1108/MIP-02-2019-0072

Tsao, W., Hsieh, M., \& Lin, T. (2016). Intensifying online loyalty! The power of website quality and the perceived value of consumer/seller relationship. Industrial Management and Data Systems, 116(9), 1987-2010. https://doi.org/10.1108/IMDS-07-2015-0293

Wobker, I., Eberhardt, T., \& Kenning, P. (2015). Consumer confusion in German food retailing: the moderating 
role of trust. International Journal of Retail and Distribution Management, 43(8), 752-774. https://doi.org/10.1108/IJRDM-07-2012-0061

Wolfinbarger, M., \& Mary, C. G. (2003). eTailQ: Dimensionalizing, Measuring and Predicting Etail Quality. Journal of Retailing, 79(3), 183-198. https://doi.org/10.1016/S0022-4359(03)00034-4

Wong, C. H., Lee, H. S., Lim, Y. H., Chua, B. H., Chai, B. H., \& Tan, G. W. H. (2012). Predicting the consumers' intention to adopt mobile shopping: an emerging market perspective. International Journal of Network and Mobile Technologies, 3(4), 24-39.

Xu, C., Peak, D., \& Prybutok, V. (2015). A customer value, satisfaction, and loyalty perspective of mobile application recommendations. Decision Support Systems, 79, 171-183. https://doi.org/10.1016/j.dss.2015.08.008

Yilmaz, V., Ari, E., \& Gürbüz, H. (2018). Investigating the relationship between service quality dimensions, customer satisfaction and loyalty in Turkish banking sector: An application of structural equation model. International Journal of Bank Marketing, 36(3), 423-440. https://doi.org/10.1108/IJBM-02-2017-0037

Zeithaml, V. A. (1988). Consumer perceptions of price, quality and value: A means and model and synthesis of evidence. Journal of Marketing, 52(3), 2-22. https://doi.org/10.2307/1251446

\section{Copyrights}

Copyright for this article is retained by the author(s), with first publication rights granted to the journal.

This is an open-access article distributed under the terms and conditions of the Creative Commons Attribution license (http://creativecommons.org/licenses/by/4.0/). 